\title{
WOMEN AND THE MEXICAN REVOLUTION,
} 1910-1920

W omen played a significant but, until recently, largely overlooked role in the complex and destructive civil war known as the Mexican Revolution of 1910-1920. ${ }^{1}$ A number of women trained and educated in the vocational and normal schools and molded by the incipient feminist movement of the Porfirian era actively sought involvement in the struggle during its various phases. A much larger number of women of the rural and urban lower classes found themselves caught up in the struggle and had no choice but to become actively involved, especially in the military aspects of the Revolution. Still others, numbering in the hundreds of thousands, and including women of every class, were among the victims and casualties of that conflict. ${ }^{2}$ Lastly, women of primarily but not exclusively middle and upperclass origins who strongly identified with the Catholic Church became active and bitter enemies of the decidedly anti-clerical leadership of the Revolution.

There were many precedents for the active involvement of women in the armed struggle of 1910-1920. Mexican writers interested in the role of the female in the epic Revolution have accentuated the fact that

\footnotetext{
'Only one monograph has appeared on the subject. See Angeles Mendieta Alatorre, La mujer en la revolución mexicana ("Biblioteca del Instituto Nacional de Estudios Históricos de la Revolución Mexicana," No. 23; México, 1961). See also Frederick C. Turner, "Los efectos de la participación femenina en la Revolución de 1910," Historia Mexicana, XVI (1966-67), pp. 603-620.

${ }^{2}$ It is believed that as many as two million Mexicans lost their lives in the Revolution. Charles Cumberland, Mexico: The Struggle for Modernity (New York, 1968), cites this figure on p. 246, calculating "that from the first three censuses and the last an approximation of a growth-rate curve may be constructed, and on such a curve the population of 1921 should have fallen between 17 and 16 million-but the census of that year counted slightly less than 14.5 million." Ibid., p. 245 . The actual figure was $14,334,780$. The 1910 census counted $15,160,369$ Mexicans, so that if both sets of figures are correct the nation had 825,589 fewer inhabitants in 1921 than in 1910. See Estados Unidos Mexicanos. Secretaría de Industria y Comercio, Dirección General de Estadística, Censo general de población, 1960; Resumen general (México, 1962), p. xxii.
} 
women had given aid and comfort and had also, when necessary, fought alongside their men in all the wars the country had previously experienced. This included the independence movement of 1810-1820, the North American invasion of 1846-1848, and the Reform War and the French Intervention of 1857-1867. ${ }^{3}$ However, the educational and vocational opportunities offered to and accepted with such alacrity by females from 1876 to 1910 added a new dimension to their participation in their country's crisis: an intellectual one. Three persons who best exemplify the intellectual contributions of women to the Mexican Revolution are the journalist Juana Belén Gutiérrez de Mendoza (18751942), the school teacher Dolores Jiménez y Muro (1848-1925), and the feminist private secretary of President Carranza, Hermila Galindo de Topete (1896-1954).

$$
\text { *** } *
$$

The journalist, poet, and political radical Juana Belén Gutiérrez de Mendoza was born in 1875 in Durango of an Indian mother and a mestizo father who worked at such varied jobs as blacksmith, horse tamer, and farm worker. ${ }^{4}$ Trained as a typographer, in 1901 Juana joined the Precursors or early critics of Don Porfirio who called for an anti-capitalist revolution by Mexico's peasants and workers against the Díaz regime. ${ }^{5}$ Angered by the foreign domination of Mexico's banks, insurance companies, mines, textile mills and railroads, aroused by the increasing impoverishment, exploitation, and debasement of the country's landless peasants and workers, and disturbed by the resurgence of the Catholic Church in Mexico, in May of 1901 Juana established an anti-Díaz newspaper, Vesper, in the extremely traditionalist provincial capital of Guanajuato. ${ }^{6}$

Fearless, combative, and an uncompromising foe of social injustice,

${ }^{3}$ This is noted by Mendieta, op. cit., pp. 22-26, and by Miguel Alessio Robles, Voces de combate (México, 1929), p. 151. Earlier, José María Vigil, director of the Biblioteca Nacional de México and a strong supporter of women's rights in the last quarter of the 19th century, noted the activist role women played during the French intervention. See his La mujer mexicana (México, 1893), Pp. 27-29. For a modern study of the role of women during the French intervention see Adelina Zendejas, $L a$ mujer en la intervención francesa ("Colección del Congreso Nacional de Historia para el Estudio de la Guerra de Intervención," No. 2; Mexico, 1962).

"Mendieta Alatorre, op. cit., p. 33.

${ }^{5}$ For an excellent study of the Precursor movement see James D. Cockcroft, Intellectual Precursors of the Mexican Revolution, 1900-1913 (Austin, 1968).

${ }^{6}$ Vesper: Justicia y Libertad, Año I, No. 1 (May 1901). 
political tyranny, and religious obscurantism, in her little newspaper Juana Gutiérrez passionately defended the wretchedly treated miners of Guanajuato. She attacked, with equal vehemence, the clergy of one of the most religiously conservative states in all of Mexico. ${ }^{7}$ Contradicting the stereotypes of timidity and religiosity ascribed to Mexican women, and attacking head-on the reactionary milieu of Guanajuato, Señora Gutiérrez early developed an inimitable style which led the Anarchist journalist and editor of Regeneración, Ricardo Flores Magón, to hail her newspaper as "virile." 8 A later admirer, Santiago R. de la Vega, stated that, like the Spanish feminist novelist Emilia Pardo Bazán, Juana Gutiérrez had "trousers in [her] style."

A few copies of Vesper and other newspapers which Juana edited from 1901 to 1941 survive in the Hemeroteca Nacional (Newspaper Archives) in Mexico City, and all of them attest to the refreshing candor, incisiveness and vigor of her writing. She castigated Díaz for failing to carry out his obligations as leader of the Mexican people, but pointed out to her readers that they and all Mexican citizens had also failed to exercise their rights. ${ }^{10}$ While millions of supposedly enfranchised Mexican men silently endured the abuses of the Díaz regime, Juana Gutiérrez protested against the harshness and brutality of Don Profirio's government, especially against workers.

The answer of the dictator was to treat Juana Gutiérrez as he treated the male foes of his regime. She was thrown into jail several times between 1904 and 1920. The horrors of the women's section of the prison of Belén in Mexico City fortified rather than broke this extraordinary woman's spirit, and she celebrated the beginning of the tenth year of Vesper in May, 1910, by assuring her readers that she was back at her post, ready once again to do battle against a tottering dictatorship. ${ }^{11}$

In May, 1910, sensing that the fall of Don Porfirio was imminent (he left Mexico for exile a year later), Juana warned her readers that "the fall of a tyrant is not the end of tyranny." 12 She endorsed and supported Francisco I. Madero, the leader of the Anti-Reelectionist Party, for President, in two editorials in the May 8, 1910 edition of Vesper. This brought the wrath of Díaz upon her once again. As prison had not

\footnotetext{
${ }^{7}$ Mendieta Alatorre, op. cit., p. 33.

Ilbid., p. 31.

9Ibid., p. 31.

${ }^{10}$ Vesper, Año III, No. 34 (July 1903), p. 1.

${ }^{1}$ Vesper, Año X, No. 1 (8 May 1910), p. 1.

${ }^{12}$ Ibid., p. 1.
} 
silenced her, her press was confiscated. Later, in July of 1911, Angela Madero, the politically active sister of the Anti-Reelectionist opponent of Díaz, saw to it that Doña Juana, never in her life a woman of means, received 2,000 pesos to indemnify her for the earlier seizure of her printing press by the recently deposed government. ${ }^{13}$

In time Señora Gutiérrez became disillusioned with Madero, who, once elected to the presidency in October, 1911, ignored her warning that Díaz's fall was not the end of tyranny. Don Francisco retained many Díaz holdovers in the government and in the military and turned against his early supporters, such as the agrarian leader Emiliano Zapata. The latter wanted land reform and an end to local political tyranny immediately and not, as Madero promised, at some vague date in the future.

In early 1919, when the most violent phase of the revolution was spent, with Madero dead since 1913, Zapata recently assassinated, and Venustiano Carranza soon to meet a bloody end for attempting to perpetuate a new tyranny, Doña Juana surveyed the revolutionary panorama from 1900 to 1919 from the pages of her new weekly, $E l$ Desmonte. The title Vesper, she said, had to go. "It was too visionary, too idealistic. . . . [Now] the countryside is bristling with old logs; one must dismount." 14

In her editorial of June 15,1919, "Desmontada," Juana Belén spoke for a war-weary and exhausted people who hungered for the social and economic justice that nine years of fratricidal strife had failed to bring about. "In general," she wrote, "the situation is not better nor worse than it was in 1900, when the movement [against Díaz] began. . . . As for the so-called principles that have been inscribed on the flags of combat, with the exception of that part of . . . [Zapata's] 'Plan de Ayala' dealing with the agrarian question, there has been nothing that scarcely merits the name of principle." 15

As for leadership, the situation was disheartening after so much struggle. One could expect little from Mexican labor, she asserted, for it was plagued by bad leadership and demagoguery. In fact, the Mexican labor movement was so disoriented from within that agents of the North American A.F. of $\mathrm{L}$. were succeeding in drawing the Mexican unions into the orbit of a country which, Juana believed, exploited not only workers but whole nations.

\footnotetext{
${ }^{13}$ Mendieta Alatorre, op. cit., p. 32.

${ }^{14}$ El Desmonte: Por la Tierra y por la Raza, Vol. I, No. 1 (15 June 1919), p. 4.

${ }^{15}$ Ibid., p. 1.
} 
One could expect even less leadership from political parties, for in Mexico, Juana wrote, "the name of party is applied to any half dozen individuals who have some very special and determined interests, interests they wish to protect by gaining office." ${ }^{16}$ And there was nothing to expect or hope for from the regime of President Carranza, for Carrancismo or Constitutionalism was pictured by Juana Belen as a cadaver "that has produced nothing but impurities, monstrosities and bastardies." 17 Nor could one expect anything from Pancho Villa, who was now a captive of reactionary forces.

For Juana Gutiérrez, Emiliano Zapata had been the most authentic voice of revolutionary Mexico, of Indian Mexico, of village Mexico. But Zapata was dead, assassinated on orders of Carranza. All the good Zapata had sought to do for the disinherited peasants of Morelos was being undone by the enemies of land and liberty.

The picture that Doña Juana painted of Mexico in 1919 was very grim, but it was realistic, as realistic as the classic novels Martín Luis Guzmán and Mariano Azuela wrote about the Revolution. Juana Belén did not despair, however, and all her life she urged workers and peasants to participate in the electoral process, "not," as she wrote, "to integrate power, but to disintegrate it, as a means of forming, not a new oligarchy, but of transforming the oligarchies into truly public administrations." 18 Juana Belén Gutiérrez de Mendoza could not be bought, could not be intimidated, could not be frightened, and could not be broken. Yet, except for the handful of Mexicans who have read her vigorous prose, she has been forgotten, while her exhortations are ignored by those who govern Mexico.

Dolores Jiménez y Muro shared much in common with Juana B. Gutiérrez. She too was a political radical (a socialist by conviction), a poet by avocation, a contributor to left-wing journals, and a fervent admirer of Emiliano Zapata. ${ }^{19}$ She too was jailed in Belén and in the penitentiary in the days of Díaz and during the counter-revolutionary government of Victoriano Huerta in 1913-1914. And Dolores Jiménez y

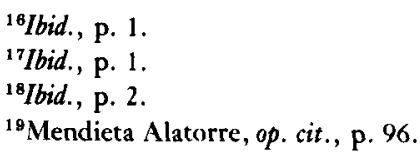


Muro was also hailed as a "viril escritora de combate" by her male revolutionary colleagues. ${ }^{20}$

If we know little of Juana Belén Gutiérrez's private life, we know hardly more about that of Dolores Jiménez y Muro, except that she was an unmarried schoolteacher who was born in Aguascalientes on June 7, 1848 and who died in Mexico City on October 15, 1925. We also know that Profesora Jiménez contributed poems and articles to various journals under assumed names and was a member of the editorial staff of the feminist journal La Mujer Mexicana in 1905. She was also active in the Precursor Movement from 1900-1910 and in the Revolution from 1910 until the death of Zapata. ${ }^{21}$

In March, 1911, Dolores Jiménez y Muro became involved in the "Complot de Tacubaya," a conspiracy intended to bring Madero to power by a rebellion near the nation's capital. ${ }^{22}$ Like all projected uprisings in Mexican history, it was preceded by a "Plan" which served to morally justify armed rebellion and which also explained the goals of the conspirators. The principal ideas of the Plan were agreed upon by the revolutionary leaders, who then turned to their esteemed colleague, Profesora Jiménez, to give form to these ideas. ${ }^{23}$ The Political and Social Plan which she put together and which was published on March 18, 1911 , is of great interest to students of the ideological currents of the Mexican Revolution. Unlike the party platforms of early 1910 or Madero's Plan de San Luis Potosí of October 1910 the schoolteacher's plan recognized the need for far-reaching social and economic reforms and not simply the desirability of a political change at the top. ${ }^{24}$

James D. Cockcroft, in Intellectual Precursors of the Mexican Revolution, 1900-1913, correctly points out that the "Political and Social Plan proclaimed by the states of Guerrero, Michoacán, Tlaxcala, Campeche, Puebla and the Federal District (March 18, 1911) was . . . a forthright continuation of the principles set down in the PLM (Mexican Liberal Party) Program of 1906, with only slight modification." ${ }^{25}$ Both documents insisted on the need for agrarian reform, maximum hours of work, and improved wages and working conditions for rural and urban work-

\footnotetext{
${ }^{20}$ Ibid., pp. 96-103.

${ }^{21}$ Ibid., p. 96. Cockcroft mentions her twice in his Intellectual Precursors, pp. 80 and 189. She was a member of the editorial staff of La Mujer Mexicana from July 15, 1905 until the end of that year.

${ }^{22}$ Gildardo Magaña, Emiliano Zapata y el agrarismo en México (2 vols., Mexico, 1934), I, 119-120.

${ }^{23}$ Ibid., I, 121.

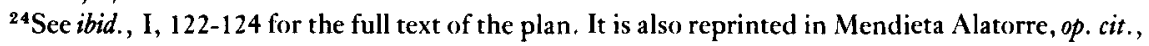
Pp. 97-100.

${ }^{25}$ Cockcroft, op. cit., pp. 188-189.
} 
ers. Both documents also called for educational reform, the restoration of municipal autonomy, and the protection of the indigenous race. ${ }^{26}$ They also gave expression to a strong economic nationalism, a crucial point on which all anti-Díaz revolutionaries agreed. Profesora Jiménez's plan stipulated that at least half the employees of any foreign firm operating in Mexico were to be Mexican nationals, whether in blue or white collar positions, and that Mexicans were to be paid the same salaries as their foreign counterparts. ${ }^{27}$

At the same time, Profesora Jiménez proposed other reforms in her plan which are not found in the July 1, 1906 PLM program drawn up by her friends and colleagues the Flores Magón brothers, Juan Sarabia, Librado Rivera and other important intellectual precursors of the Revolution. ${ }^{28}$ For example, point seven of her plan called for the decentralization of Mexico's educational system. Carranza may very well have had Señorita Jiménez's idea in mind when he assumed leadership of the Revolution and was in control of Mexico City by mid-1915. Beginning in that year he sought to abolish the highly centralized educational system in Mexico and substitute it with one which allowed the localities to finance and control their own schools. The noble experiment came to an end when Alvaro Obregón succeeded to the presidency in 1920, for only the Federal Government collected enough taxes to finance the schools, inadequate as they were, that had existed in the Republic up to 1915. The decline, from 1915 to 1920 , in the already low educational standards evidently led to a return to the highly centralized system of the prerevolutionary period.

Profesora Jiménez also diverged from her colleagues' 1906 platform in devoting one of the fifteen points of her plan to what is still one of Mexico's most serious problems-expensive and inadequate housing for the vast majority of Mexican urban dwellers. In her many years as a schoolteacher in urban schools, Profesora Jiménez was no doubt deeply distressed by the wretched housing available to the families of the children she taught. She was also probably very conscious of the relationship between unsanitary housing and poor health. In point 13 of her revolutionary plan, Dolores Jiménez y Muro urged that as soon as circumstances permitted, the value of urban properties was to be revised in order to establish equitable rents and in order to insure that poor people were no longer forced to pay relatively high rents to real

\footnotetext{
${ }^{26}$. The full text of the PLM 1906 platform is found in ibid., pp. 239-245.

${ }^{27}$ Point 12 in the 1911 Plan Político Social in Mendieta Alatorre, La mujer en la revolución mexicana, p. 97.

${ }^{28}$ Cockcroft, op. cit., pp. 129-133.
} 
estate speculators. She hoped that eventually real estate taxes would be used "in order to construct comfortable and hygienic housing for the working classes, to be paid for in long-term installments." ${ }^{29}$

Dolores Jiménez y Muro left her personal imprint on the March 1911 Social and Political Plan by specifying, as no other contemporary revolutionary plan did, that the daily wages of rural and urban workers of botb sexes were to be increased. The schoolteacher, herself a wage earner, seems to have been more aware than her male colleagues that large numbers of women worked outside of the home. Although the 1910 census judged that women made up only $8.8 \%$ of the "economically active" population in the Republic, in 1902 at least $17 \%$ of the workers in the textile industry, most of it foreign-owned, were women. ${ }^{30}$ What was happening in Mexico by 1910 was a phenomenon to be observed in every industrializing country. "Once economic production moved to the factory," observes Mirra Komarowsky in Women in the Modern World, "women were forced to follow their work beyond the confines of their homes." ${ }^{31}$ Señorita Jiménez was keenly aware of this fact, and was also conscious that, contrary to the conclusions drawn by the 1910 census, many women in the rural areas also worked outside the home.

The 1910 Mexican census' determination that females made up only $8.8 \%$ of the economically active population bears examination, as at least one writer interested in the role women played in the 1910 revolution has cited these census figures as evidence that until the coming of the Revolution women lived in seclusion at home. ${ }^{32}$ What the directors of the 1910 census did was to imagine that a clear-cut division of labor between the sexes existed in Mexico, that men were the providers and women the homemakers. ${ }^{33}$ Actually, in 1910 about $80 \%$ of the population had been largely unaffected by the modernization that took place between 1876 and 1910, and in Mexico, as in all other pre-industrial societies, "women were also economic providers through the multitude of goods and services supplied by home industry." 34 The 1910 census ignored the fact that in rural areas women spent most of their time

\footnotetext{
${ }^{29}$ Mendieta Alatorre, op. cit., p. 97.

${ }^{30}$ Donna M. Wolf, "Women in Modern Mexico," (unpublished essay, 1975), quoting Antonio Peñafiel, Estadística industrial (México, 1902), pp. 2-72 and passim. See also Ana María Hernández, $L a$ mujer mexicana en la industria textil (México, 1940), pp. 27-38, for the active role of women in the textile workers' strikes of 1907 and in the precursor movement.

${ }^{31}$ Mirra Komarowsky, Women in the Modern World: Tbeir Education and Their Dilemmas (Boston, 1953), p. 50.

${ }^{32}$ Frederick C. 'Turner, Tbe Dynamic of Mexican Nationalism (Chapel Hill, 1968), p. 185.

${ }^{33}$ Mirra Komarowsky, op. cit., p. 50.

${ }^{34}$ Ibid., p. 50 .
} 
outside the home, raising animals, fruits, vegetables and flowers for sale in town and village markets, when they could ${ }^{35}$ or working as peons alongside the men when they were landless. The 1910 census takers also ignored the women living in the vicinity of railroad stations, who spent a large part of the day preparing food to sell to hungry passengers travelling on second and third class coaches on the nation's 15,000 kilometers of railroads. This phenomenon is still observable when one travels by train in Mexico today.

Other economically active women who escaped the attention of the census takers were women artisans, piece workers, street vendors, boarding house owners, and many other working women deemed "economically inactive" by short-sighted bureaucrats in Mexico City. Naturally, working women did nothing to correct the erroneous impressions held by the census takers. An admission that they earned money might have led unwelcome tax collectors to their door, and in addition, would have deflated male pride. Since most of the questions asked by the census takers were probably answered by or in the presence of male members of the household, it is understandable that few men were willing to admit to outsiders that their wives or daughters or sisters were providers. Instead, they told the census takers what they wanted them to hear, which the latter were predisposed to believe anyway. Profesora Jiménez y Muro was more attuned to reality, and sought to bring the problem of working women to the attention of the revolutionary leaders.

When Emiliano Zapata was shown a copy of Profesora Jiménez's plan and saw that point nine called for the restitution of usurped village lands, he said to Gildardo Magaña: "that is exactly what we are fighting for-so that the lands we were robbed of shall be returned." ${ }^{36}$ When Zapata was told that the plan was written by a very "enthusiastic, cultivated and revolutionary señorita," the agrarian leader said he had need of such people in his ranks, and he expressed the wish that she and other intellectuals would join his cause in the state of Morelos. After the death

\footnotetext{
${ }^{35}$ Of women's work in the rural community of San José de Gracia, Michoacán between 1861 and 1882, Luis González observes that "most of the hard work fell to the women: grinding corn on the metate, making tortillas, cooking meals for the men, keeping the fire going, cleaning, washing clothes, sewing, darning, carrying water, scolding their husbands and children, taking care of the pigs and chickens, bleaching wax, making cheese, weaving-in short, keeping so busy with household chores and home industries that they got no rest. It was only the men who could allow themselves the vice of idleness." Luis González, San José de Gracia: Mexican Village in Transition ("The Texas Pan American Series," Austin, 1974), p. 49. For examples of the work rural women perform outside the home in contemporary Mexico see Mary L. Elmendorf, La mujer maya y el cambio ("SEP-SETENTAS," No. 85; México, 1972), passim.

${ }^{36}$ Magaña, Emiliano Zapata y el agrarismo en México, I, 125.
} 
of Madero, Dolores Jiménez y Muro joined the legendary leader of the South and remained in Morelos until Zapata's assassination in 1919. ${ }^{37}$ By then Señorita Jiménez, an active revolutionary since 1900, had passed her seventieth birthday. Despite her contributions to the Mexican Revolution, she has received little attention from students of that conflict.

Of all the women who participated in some way in the Mexican Revolution, none was better known, between 1915 and 1919, nor more influential, than Hermila Galindo. ${ }^{38}$ She was the author of several feminist and political tracts, editor from 1915-1919 of the feminist journal Mujer Moderna, and one of Carranza's most energetic propagandists in Veracruz, Tabasco, Yucatán, Campeche, and other Mexican states. $^{39}$ In addition, Galindo represented Carranza abroad and in September, 1916 gave a series of public lectures explaining "Carranza's Doctrine" in Havana, Cuba ${ }^{40}$ Then, in 1919, her public career came to an abrupt end, and though she lived until 1954 Hermila Galindo took no part in the feminist movement of the 1920s and 1930s, a movement she helped to inspire.

Her spectacular rise and enigmatic fall raise a number of questions about Hermila Galindo that have not been pondered before. How is it that such a young woman-she was only fifteen when the Revolution broke out-became the most prominent exponent of feminism in Mexico during the Carranza era? Why did her career come to such a sudden end in 1919, followed by complete silence and oblivion for the remainder of her life? What specific ideas and strategies did she contribute to the women's movement that developed during and after the Mexican Revolution?

Hermila Galindo became the most prominent exponent of feminism in

\footnotetext{
${ }^{37}$ Ibid., I, 126.

${ }^{38}$ For an interesting evaluation of her own career, see Hermila Galindo, La doctrina Carranza y el acercamiento indolatino (México, 1919), pp. 159-161.

${ }^{39} \mathrm{Ibid}$., Pp. 160-161, and Mendieta Alatorre, op. cit., Pp. 79-80. No copies of Mujer Moderna were found in the Hemeroteca Nacional in Mexico City, but two essays Ms. Galindo prepared for the first and second feminist congresses in Mérida summarize her views on women. The first is "La mujer en el porvenir," (November 29, 1915) and the second is "Estudio de la Srita. Hermila Galindo con motivo de los temas que han de absolverse en el segundo Congreso feminista de Yucatán," (November 20, 1916).

${ }^{40}$ Galindo, op. cit., p. 161.
} 
Mexico between 1915 and 1919 because she had skills and abilities which Carranza was shrewd enough to recognize and exploit. Born in Lerdo, Durango in northern Mexico in 1896, Hermila Galindo was a precocious and diligent student. She studied English and became an accomplished stenographer and typist by the time she was fifteen. ${ }^{41}$ Moving to Mexico City in 1911, she joined the Liberal "Abraham González" Club in that city. A gifted speaker, she was named orator of the club and was selected to give a welcoming speech to Carranza upon his triumphal entry into the capital after the fall of the counter-revolutionary government of General Victoriano Huerta. ${ }^{42}$

Carranza was impressed with the young woman's enthusiasm and oratorical skill and invited her to join his government, which was temporarily moved to Veracruz in late 1914 when his rivals Zapata and Pancho Villa drove him out of Mexico City. In his effort to build up political support to counter the popularity of Zapata and Villa among the masses, in 1914-1915 Carranza wooed representatives of worker and peasant groups in his unrelenting drive for the presidency. Similarly, he sought the support of women, or hoped at least to reduce their enmity against his conspicuously anti-clerical positions. He found a willing ally in Galindo, who wrote newspaper articles and gave numerous speeches before women's groups, extolling Carranza's leadership abilities. She also urged women to join revolutionary clubs, no doubt to counter the influence of Catholic women's groups which were becoming bastions of anti-revolutionary sentiment. Ms. Galindo also began publication of the journal, Mujer Moderna, which had the twin aim of promoting feminist ideas and supporting Carranza's bid for power. She steadfastly supported Carranza after he was elected president in 1917, and remained loyal to him despite mounting criticism of his venality, duplicity, and bad faith as the supposed leader of Mexico's peasantry and urban working classes. ${ }^{43}$

There are a number of reasons why Hermila Galindo's career came to an abrupt end in 1919. First of all, her continued association with Carranza and her well-known role of propagandist for his cause made all of his enemies her enemies. Secondly, in 1919 she supported the wrong man to succeed Carranza in the presidency (General Pablo González),

\footnotetext{
"Mendieta Alatorre, op. cit., p. 79.

${ }^{42}$ Ibid., pp. 79-80.

${ }^{4}$ Galindo, op. cit., pp. 1-16 and passim.
} 
thus losing Carranza's confidence without gaining that of the men who were to wield power in Mexico after Carranza's demise. ${ }^{44}$ Thirdly, her ideas were anathema to most "revolutionaries", not to speak of conservative Mexicans. Emboldened by Carranza's support, between 1915 and 1919 Hermila Galindo adopted advanced positions on divorce, sexuality, religion, prostitution, and politics which shocked even secular-oriented middle-class women with some education. ${ }^{45}$

After General Alvaro Obregón succeeded to the presidency in 1920, Ms. Galindo no coubt discovered that she was "quemada" (burned), one of the "outs" whose attempt to regain influence would be blocked at every turn. In 1923 she married Manuel de Topete, and we hear no more of her after that. ${ }^{46}$ Presumably she settled down to the busy life of housewife and mother. Her feminism, it would appear, had been a youthful fling. And her sudden fall from favor in 1919 was a warning to other feminists that close association with an incumbent president was not the most effective way to pursue feminist goals in Mexico.

Yet despite the brevity of Galindo's career as a feminist, she left her mark on the women's movement in Mexico. A number of the ideas she championed were endorsed by prominent feminists in the 1920s and 1930 s and at least one of her strategies for drawing attention to the feminists' demand for political equality was to be used over and over again by activists from 1925 until 1940 .

Hermila Galindo was one of Mexico's first feminists to frankly state that the Catholic Church was the chief obstacle to the promotion of feminism in the country. She maintained that the Mexican Church, which had remained impervious to change throughout the nineteenth and early twentieth centuries, was the principal agent of the subjection of women. Galindo was convinced that the hierarchy would oppose at every turn the movement for women's rights in Mexico through its control of Catholic women's organizations and its influence anong conservative newspaper editors. Feminists of the Porfirian era had made no references to religion in public, for although they might have

\footnotetext{
${ }^{44}$ Hermila Galindo, Un presidenciable. El General don Pablo González (México, 1919). Carranza chose Ignacio Bonillas, Mexican ambassador to the United States, to succeed him while Alvaro Obregón led the successful revolution to oust Carranza. See Charles Cumberland, Mexican Revolution: The Constitutionalist Years (Austin, 1974), pp. 404-413.

${ }^{43}$ Ms. Galindo notes in her November 1916 "Estudio" (see footnote 39 for the complete title) that her "La mujer en el porvenir" aroused a storm at the First Feminist Congress of Yucatan because her ideas "afectaban hondas preoccupaciones que tienen su raiz en el pasado," p. 5.

${ }^{46}$ Mendieta Alatorre, op. cit., p. 80. Mendieta states that Hermila Galindo continued to write books and articles after Carranza's death, most of which were never published. Ibid., p. 80 .
} 
privately held views similar to those of Galindo, they knew that any expression of anti-clerical views would offend public sensibilities, especially at a time when Don Porfirio was busy reducing Church-State antagonisms. ${ }^{47}$

However, a new surge of extreme anti-clericalism developed during the Revolution, for the Church had become so identified with the Porfirian regime that the revolutionaries, whether liberals, socialists, anarchists, or nationalists, all agreed that the power and influence of the Church had to be curbed. As a result of the near unanimity among revolutionaries, a number of articles of Mexico's 1917 constitution went beyond the anti-clerical measures of the 1850s and 1870 s and sought, among other things, to drastically reduce the number of clergy in Mexico and to prohibit Church schools from functioning. ${ }^{48}$ Hermila Galindo's anti-clerical stance reflected the mood of this period. While feminists after Galindo avoided references to religion and the Church in their public utterances to gain as wide a following as possible, most of them had no allegiance to the Catholic Church, while a few became prominent in the Protestant YWCA. ${ }^{49}$

One of the chief challenges to the Catholic Church in the revolutionary period was Carranza's proposal, which was adopted by most Mexican states in 1915-1917, that divorce be permitted in Mexico. Until his divorce decree of January 29,1915 , only legal separation was in force in the country. After that date remarriage was legal. Hermila Galindo staunchly endorsed the Carranza decree, agreeing with him that divorce would have a "moralizing effect" in Mexico. ${ }^{50}$ She believed that it would be a great boon to unhappily married women, and her position was adopted by the more advanced and secular-oriented feminists of her day and by mainstream feminists in the late 1920s and 1930s. If there were objections to the divorce decree by feminists it was in large part because Carranza's law discriminated blatantly against women.

\footnotetext{
${ }^{47}$ Ms. Galindo's views on women and the Church are most fully explored in her November 1916 "Estudio," pp. 14-18.

${ }^{48}$ For an article by article comparison of the 1857 and 1917 Constitutions, see $H$. N. Branch, trs. and ed., "The Mexican Constitution of 1917 Compared with the Constitution of 1857," in The Annals of the American Academy of Political and Social Science, Vols. 69-71 (Jan.-May, 1917). Article 3 of the 1917 Constitution prohibited any Church or minister from directing schools of primary education. Article 130 forbade foreign clergymen in Mexico and permitted the States to limit the number of clergy who could officiate within their boundaries. See ibid., pp. 2 and 103-106.

${ }^{49} \mathrm{~A}$ good example was the feminist Elena Landazuri, who was President of the YWCA in Mexico in the early 1920s. See Ida C. Clarke and Lillian B. Sheridan, eds. Women of 1924 International (New York, 1924) pp. 253-254.

${ }^{50}$ Galindo, "Estudio . . ." (November 20, 1916), pp. 18-20.
} 
Hermila Galindo was also very frank in her endorsement of sex education in the schools, arguing that the major reason why women were held in subjection was because of religious preoccupations, ignorance and an absurd lay education. She shocked the country's more moderate feminists when, in her "La mujer en el porvenir" (Woman in the future), read at Mexico's first feminist congress in Yucatán in January 1916, she argued that women have a strong sex drive. She insisted that women needed to understand the nature of their sexuality and that schools needed to include a study of the human reproductive system in a required course in biology. Once again she brought up the relation of women and the Church by asserting that "religion has wanted woman to ignore her sexuality in order to always keep her in ignorance and in order to exploit her." ${ }^{11}$ Her plea for recognition and understanding of female sexuality and for the need for sex education in the public schools received little support at the time. However, the need for sex education in the schools became a consistent part of feminist demands in the succeeding decades and during the presidency of Lázaro Cárdenas (1934-1940) sex education in the public schools was first introduced on the national level. ${ }^{52}$

Hermila Galindo insisted that women should enjoy the same rights and privileges as men, and that to achieve equality females needed a modern, relevant, and well-rounded education. Galindo affirmed that woman had to get rid of the pervasive idea that she was useful only for bearing and raising children; she had to break away from the yoke of ignorance that reduced her to "a being without consciousness and without aspirations." 53 With a proper education, Galindo maintained, women "would appreciate the advantages of independence and the beauties of truth."

Galindo also joined the pre-revolutionary feminists in inşisting that the first step to achieving equality of the sexes was to drastically revise the civil code, as it extinguished the legal personality of married women. ${ }^{55}$ Pressure for revision of that code led Carranza to issue the Law of Family Relations in 1917 and to a steady campaign for the preparation of a revised civil code, which was finally completed in 1926.

Hermila Galindo was one of the earliest feminists to insist that, to

\footnotetext{
${ }^{51}$ Hermila Galindo, "La mujer en el porvenir," (Mérida, Yuc., 1915), pp. 1-12.

${ }^{52}$ José Castillo y Pina, Cuestiones sociales (México, 1934), pp. 162-164.

${ }^{53}$ Galindo, "Estudio . . ." (November 20, 1916), p. 12.

${ }^{54}$ Ibid., p. 12.

55Ibid., p. 14.
} 
achieve legal equality, women first of all had to be given the right to vote. ${ }^{56}$ Before 1910 few feminists talked about suffrage, no doubt because effective suffrage had never been a reality in Mexico. But Madero's revolution and his insistence on "effective suffrage and no re-election" kindled a new interest in the need for democratic procedures in Mexico, and with it came an interest in woman suffrage among the more advanced feminists. ${ }^{57}$ Galindo argued that women pay taxes and contribute to society when they work for a living. A woman was as liable to the law as any man, she noted, and must obey the government. Galindo added that if women were guilty of breaking the law they were also liable to the same penalties as men. This being the case, she concluded, there were no rational grounds for denying women the right to vote and run for office. ${ }^{58}$

When Carranza called a constitutional convention to meet at Querétaro to revise the 1857 constitution, Hermila Galindo and a number of other women petitioned its members to provide for woman suffrage. ${ }^{59}$ However, Felix Palavicini, Carranza's education director, was the only member of the Querétaro convention to seriously champion the feminists' cause. His colleagues simply ignored or laughed at his proposal that they at least debate the question of woman suffrage. ${ }^{60}$

Shortly after the 1917 Constitution was completed and its provisions made public, Hermila Galindo, backed by hundreds of supporters, informed the leading newspapers in Mexico City, including Palavicini's El Universal, that she intended to run for a seat in the Chamber of Deputies in the coming elections. ${ }^{61}$ Galindo made it clear that she had no hope of being elected, but that she had two other objectives in mind. One was to bring to the attention of the nation and its leaders the large number of women who wanted to vote. The other was to set a precedent for the next generation. ${ }^{62}$

The electoral law of 1918 dashed the hopes of Hermila Galindo and other feminists by limiting the vote to males. However, during the $1920 \mathrm{~s}$

\footnotetext{
${ }^{56}$ Ibid., p. 25.

${ }^{57}$ At the First Feminist Congres held in Mérida, Yucatán in January, 1916 the majority of the delegates approved a motion that women be permitted to vote in municipal elections. See Congreso Feminista de Yucatan, Anales de esa memorable asamblea (Mérida, Yuc., 1916), p. 127.

${ }^{58}$ Galindo, "Estudio ..." p. 25.

${ }^{59}$ Mendieta Alatorre, op. cit., p. 80.

${ }^{60}$ Fernando Romero García, ed., Diario de los debates del congreso constituyente (2 vols.; México, 1917), II, 708-709.

${ }^{61} L a$ Voz de la Revolución (Mérida, Yuc.), March 15, 1917, p. 1.

${ }^{62}$ Ibid., p. 1.
} 
and 1930s feminists employed Galindo's tactics by showing up at the polls on election day and by campaigning for office in order to force the Mexican Congress to change the electoral law. Their efforts were not rewarded until the period after World War II. In Mexico, as in France, it was the fear that the vast majority of women would vote for Churchendorsed candidates that delayed woman suffrage until this fear could be allayed.

Unlike her contemporaries Juana Belén Gutiérrez de Mendoza and Dolores Jiménez y Muro, Hermila Galindo did not suffer imprisonment for expressing her ideas. However, she did have to face a great deal of hostility, scorn and ridicule from both men and women for expressing unpopular views and for speaking up on subjects which still remain taboo in Mexico ${ }^{63}$ Her willingness to face strong opposition gave heart to the more advanced feminists of her own, and to the succeeding generation.

$$
* \quad * \quad *
$$

In addition to these three outstanding women of the revolutionary era, many other educated, middle-class females, the greater part of them schoolteachers, took an active part in the Revolution of 1910-1920. When Francisco I. Madero decided to run for the presidency against Díaz in the 1910 elections, women established their own liberal, antireelectionist clubs or were invited to participate in Maderista political clubs established by men. ${ }^{64}$ Typical of these women were Julia Nava de Ruiz Sánchez, a teacher and writer who was an active feminist all her adult life. She participated in the pre-revolutionary feminist movement and was one of the founders of the "Sociedad Protectora de la Mujer" in $1904 .{ }^{65}$ She was also an early critic of Díaz and joined the Precursor Movement at the same time that she affiliated with feminists seeking to help working-class women. ${ }^{66}$

Another Normal School graduate who joined the political opposition to Díaz was Profesora Elisa Acuña y Rossetti, who in 1903 was made a member of the "Mesa Directiva" of the opposition "Ponciano Arriaga" Confederation of Liberal Clubs. Profesora Acuña aided Juana Gutiérrez in publishing Vesper, and like her associate was imprisoned in Belén prison for opposing Don Porfirio's government. After Madero's assassi-

\footnotetext{
${ }^{63}$ Galindo, op. cit., p. 159.

${ }^{84}$ Mendieta Alatorre, op. cit., pp. 34, 79, 93 and 174.

${ }^{65}$ La Mujer Mexicana, March 1, 1904, p. 9 and July 5, 1907, pp. 61-62.

${ }^{66}$ Mendieta Alatorre, op. cit., p. 111.
} 
nation she followed the example of Profesora Jiménez and joined Zapata in Morelos. ${ }^{67}$

A third Normal School graduate, María Arias Bernal, was a fervent Maderista who, after Madero's death, was jailed by Huerta for holding periodic demonstrations against his government at the grave of Madero. ${ }^{68} \mathrm{~A}$ fourth woman to join the political opposition to Díaz and later to Huerta was María Hernández Zarco, a typesetter who worked at various printing establishments in Mexico City from 1910 to 1913. When her employer refused to print Senator Belisario Dominguez's speech denouncing Huerta as a tyrant, the young woman agreed to print the speech that night, knowing full well that her action might cost her her job as well as her freedom. ${ }^{69}$ She printed and delivered the speech to the Senator, and on October 7, 1913, Belisario Domínguez, who was to pay with his life for his courageous denunciation of Huerta, stated in his last speech in the Senate:

My fellow senators, I am happy to tell you that I found someone willing to print this speech. Do you wish to know, gentlemen, who printed it? I shall tell you, for the honor and glory of the Mexican woman. A young lady printed it. ${ }^{70}$

That night Senator Domínguez was murdered, but as a street in Mexico City named after him attests, he was not forgotten. However, as her only memorialist laments, María Hernández Zarco is completely forgotten. ${ }^{71}$

In the period from 1909 to 1913 large numbers of women also signed public protests and took part in dangerous demonstrations. For example, on September 6, 1910 a number of women in Mérida, Yucatán sent a petition to the wife of Porfirio Díaz asking her to intercede with her husband in behalf of a national amnesty for political prisoners. ${ }^{72} \mathrm{~A}$ few days later, members of a feminist club in Mexico City, the "Hijas de Cuauhtémoc" were part of a peaceful group of anti-Díaz demonstrators who were arrested as they sought to place floral wreaths at the tomb of

${ }^{67}$ Ibid., pp. 30, 31, 34 and 40.

69 Ibid., p. 93 and Alessio Robles, Voces de Combate, pp. 151-152.

${ }^{69}$ Aurora Fernández, Mujeres que bonran a la patria (México, 1958), pp. 67-70.

70Ibid., p. 71.

${ }^{71}$ Ibid., p. 71.

${ }^{72}$ David A. Franz, "Bullets and Bolshevists. A History of the Mexican Revolution and Reform in Yucatán, 1910-1924" (unpublished Ph. D. dissertation, Department of History, University of New Mexico, 1973), p. 36. 
the heroes of independence. This same group had previously collected 1,000 signatures calling for Díaz to step down and permit a truly free election to take place. ${ }^{73}$

When armed rebellion proved to be the only means of removing Díaz from office, middle-class women participated in the struggle in a number of ways. They gave money to various revolutionary groups and engaged in a number of undercover activities, including the gathering of arms and ammunition, expediting letters, and passing on information to revolutionaries. ${ }^{74}$ During the fighting, a number of women served as nurses, both on the field of battle and behind the lines.

One of the most celebrated nurses of the revolutionary period was Beatriz González Ortega (born in 1873) who, at the outbreak of the Revolution, was director of the Normal School in Zacatecas. In June of 1914 she turned the school into an emergency hospital when Pancho Villa and his army attacked the city. She and her associates tended the wounded of both sides, whether Federal troops or Villistas. When Pancho Villa triumphed, he demanded to know who among the wounded were Federal troops, as it was his practice and general practice among most of the guerrilla leaders to routinely execute their prisoners. Profesora González, who had previously burned the tell-tale uniforms of the wounded, answered that she made no distinction between Federals or revolutionaries and that "here I tend only wounded Mexicans."75 Pancho Villa immediately ordered that she and the doctor who was helping her be whipped until they identified the Federal troops. They received the lashing with stoicism, but still refused to talk. Furious, Villa ordered that she and the doctor be shot. At the last minute friends of the teacher intervened, and Villa relented. Beatriz González Ortega apparently taught Pancho Villa a lesson in the quality of mercy, for he treated her with the greatest respect for the remainder of the revolution. The courage and humanity of Profesora Gonzalez was not forgotten, and in 1955 a school bearing her name was inaugurated at Fresnilla, Zacatecas. $^{76}$

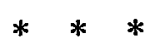

While sheltered middle and upper-class Mexican women could avoid involvement in the Revolution, this was not true of most rural and urban

\footnotetext{
${ }^{73}$ Turner, "Los efectos de la participación femenina en la Revolución de 1910," p. 611.

${ }^{74}$ Mendieta Alatorre, op. cit., pp. 173-174.

${ }^{75}$ Fernández, Mujeres que bonran a la patria, pp. 121-130.

${ }^{76}$ Ibid., p. 130.
} 
lower-class women. These women of the popular classes became the famed soldaderas of the Revolution, the women who accompanied the military units. José Clemente Orozco immortalized them in his easel paintings of Zapatistas, the graphic artist José Guadalupe Posada glamorized them on the covers of widely distributed popular ballad sheets, and the lens of the photographer Casasola captured their true image. ${ }^{77}$ The soldadera peoples the novels of the Mexican Revolution, and is the subject of revolutionary songs as "Valentina," "Adelita," and "Marieta." Foreign observers of the Revolution, as John Reed and Rosa E. King, made her a familiar figure to the English speaking world.

Yet the word soldadera, as it applies to a clearly observable phenomenon in Mexican history, is not to be found in standard dictionaries of the Spanish language, even in dictionaries which include Spanish-American colloquialisms. ${ }^{78}$ This may account, in part, for the varying translations of the word into English. Robert Quirk insists on calling soldaderas "camp followers," 79 while Frederick C. Turner refers to them politely as "lady soldiers." ${ }^{80}$ However, the most accurate translation of the term is supplied by Rosa E. King, whose Tempest Over Mexico records this remarkable Englishwoman's experience in revolutionary Mexico. Mrs. King refers to the soldadera as simply "the Mexican soldier's woman." Francisco L. Urquizo, who fought in the Revolution and later wrote novels about it, concurs with Mrs. King's description and adds: "si es soldadera tiene que seguir a su hombre, sea donde sea." 82 ("If she is a soldadera, she must follow her man, wherever that may be.")

The Mexican soldadera followed her man when he left home and

\footnotetext{
${ }^{77}$ Turner in Tbe Dynamic of Mexican Nationalism, p. 197 notes: "Depicting soldaderas in individual portraits, battle scenes and on the covers of widely distributed popular ballad sheets, José Guadalupe Posada uniformly portrayed them as beautiful, well-groomed, and determined young ladies." For photographs of read soldaderas, see Gustavo Casasola, Historia gráfica de la revolución mexicana: 1900-1960 (4 vols.; México, 1960), II, 720-723.

${ }^{78}$ See, for example, Real Academia Española, Diccionario de la lengua española (Madrid, 1956); Martín Alonso, comp., Diccionario del español moderno (Madrid, 1968); Mariano Velázquez de la Cadena, et. al., comps., Velázquez Spanish and Englisb Dictionary (Chicago, 1964); and Arturo Cuyas, comp., Appleton's New Englisb-Spanish, Spanisb-Englisb Dictionary (New York, 1940).

${ }^{79}$ Robert E. Quirk, The Mexican Revolution and the Catbolic Cburch, 1910-1920 (Bloomington, Ind., 1973), p. 58.

${ }^{80}$ Turner, The Dynamic of Mexican Nationalism, p. 183.

${ }^{81}$ Rosa E. King, Tempest Over Mexico: A Personal Cbronicle (New York, 1944), p. 183.

${ }^{82}$ Quoted by Mary L. Scalise Regoli, "La mujer en la novela de la revolución" (unpublished M.A. thesis, Escuela de Verano, Universidad Nacional Autónoma de México, 1963), p. 106.
} 
joined a large fighting force. When and if he died, she became another soldier's woman, as John Reed pointed out in his poignant account of Elisabetta in Insurgent Mexico. ${ }^{83}$

The soldadera made her first appearance in Mexican history during the independence movement, and in that conflict, as in all subsequent wars in Mexico, the opposing armies had no commissary or medical corps. They depended on women to forage for and prepare the soldier's food, wash their clothes, and tend their wounds. ${ }^{84}$ In 1901, Julio Guerrero in La génesis del crimen en México provided a vivid description of soldaderas:

[They are the women] who accompany the husband or lover on his military marches, carrying a child, a basket filled with clothing, and working utensils. In the abandoned battlefield they carry water to their wounded masters, and despoil the dead of their clothing. . . . They are jealous and courageous . . . and their moral code has two precepts . . . absolute fidelity and unconditional abnegation for the husband or lover, and respect for the officers of the battalion or regiment. ${ }^{85}$

Rosa E. King had many opportunities to observe soldaderas in the state of Morelos, for as she herself noted, "the Zapatistas were not an army; they were a people in arms." ${ }^{86}$ She praised their patience, stoicism, resignation, resourcefulness, and perseverance, qualities which made it possible for them and the men they tended to survive. Mrs. King wrote:

The wonderful soldiers' women-none like them in the world for patience and bravery at such times-combed the town [Cuernavaca] for food, and when they could not get it any other way they stole, whatever and wherever they could, to nourish their men. These were the type of women who one day, in the north, when their men ran short of ammunition, tied their rebozos to the ammunition cart and hauled it to them. I bow in respect to the Mexican women of this class.... The Mexican woman who marched with the Mexican soldier, who went before him to the camping place to have refreshment ready, who nursed him when sick and comforted him when dying, were helpers and constructionists, doing their part in laying the foundation of this liberal government of today. ${ }^{87}$

\footnotetext{
${ }^{83}$ John Reed, Insurgent Mexico (New York, 1914), pp. 99-109.

${ }^{84}$ Casasola, Historia gráfica de la revolución mexicana, II, 720.

${ }^{85}$ Julio Guerrero, La genesis del crimen en México (México, 1901), pp. 163-164, as quoted in Donna

M. Wolf, "Women in Mexico, 1810-1910," (unpublished essay, 1974), p. 5.

${ }^{86} \mathrm{King}$, Tempest Over Mexico, pp. 93-94.

${ }^{87}$ lbid., p. 183.
} 
To be sure not all the women who accompanied the military units were self-abnegating angels of mercy. The fighting, as Charles Cumberland reminds us, was vicious and bloody, ${ }^{88}$ and some women, already hardened by a life of misery and degradation before the Revolution, turned vengeful and sadistic during the fighting. A good example is La Pintada (Painted Woman) in Mariano Azuela's realistic novel of the Mexican Revolution, The Underdogs. Although Azuela does not tell us anything about La Pintada's life before the Revolution, she conforms exactly to R. H. Mason's description, in 1849, of Mexican women among the unemployed poor in urban centers. He noted that such women "are accustomed to brawls and warfare, and are in the habit of carrying concealed knives with them as a matter of course." 89

Extept in emergencies, the soldaderas did not normally bear arms or participate in the actual fighting. In addition, soldaderas were to be found only in the columnas gruesas (heavy military columns) that usually, but not always, travelled by train. ${ }^{90}$ Gustavo Casasola notes, however, that some women joined columnas volantes (flying columns) as soldados rasos (privates) and, if they proved themselves in battle, were made officers and leaders of men. ${ }^{91}$ He noted that such women

needed to masculinize themselves completely; both inwardly and outwardly: dress like a man and act like a man; go on horseback, like the rest, be able to endure long marches and, at the hour of combat, prove with weapon in hand that she was no longer a soldadera, but a soldier. ${ }^{92}$

Rosa E. King observed the phenomenon of women soldiers among the Zapatistas, and early on in her book she noted that when President Madero met Zapata in Cuernavaca on July 12, 1911, "Zapata arranged a 'review' in his honor. . . . Among the troops were women soldiers, some of them officers." ${ }^{93}$ One of these women might very well have been

\footnotetext{
${ }^{88}$ Cumberland, Mexico: The Struggle for Modernity, p. 245.

${ }^{89}$ R. H. Mason, Picture of Life in Mexico, 1849 (London, 1851), p. 62, as quoted in Wolf, "Women in Mexico, 1810-1910," p. 5.

${ }^{90}$ Casasola, op. cit; II, 720. Turner observes that "the Mexican soldiers in both federal and revolutionary ranks took their women along with them in the railway cars that carried belligerents from one part of Mexico to another. The soldaderas . . provided a commissariat for Mexican troops, and both federal and revolutionary chieftains regularly provided for their transportation along with the troops in the major campaigns." 'Turner, The Dynamic of Mexican Nationalism, p. 185.

${ }^{91}$ Casasola, op. cit., II, 720.

${ }^{92}$ Ibid., II, 720.

${ }^{83}$ King, Tempest Over Mexico, p. 69.
} 
Coronela María de la Luz Espinosa Barrera of Yautepec, Morelos, whose service record shows that she was on active duty as a Zapatista from 1910 to $1920 .^{94}$ In 1973 La Coronela was 86 years old and in failing health, but despite age and infirmity she remained a gifted raconteur with a phenomenal memory. Her remarkable narrative of her rise from soldado raso to colonel in Zapata's army, which was taped over a period of many hours in 1973-74, is the stuff of which novels are made. In fact, La Coronela of Yautepec bears some resemblance to "La Negra Angustias" of the novel of the same title by Francisco Rojas Gonzalez. Rojas modelled his character on a real woman, Remedios Farrera, who, like María de la Luz Espinosa Barrera, rose to the rank of colonel during the Revolution. ${ }^{95}$ There are some interesting parallels in the lives of both women before the Revolution. In both cases, their mother died at their birth. Neither father remarried and both women felt sharply the pain and loneliness of being a motherless child. Both took care of goats as a child, and the goats provided them with both nourishment and companionship. On December 8, 1973 La Coronela tearfully recalled, at a party celebrating her 86th birthday, that when she was very small other children asked her who her mother was, who nourished her. She pointed to a favorite goat amid the peals of laughter of her insensitive peers.

In both cases they killed someone, La Negra Angustias a man who tried to rape her and La Coronela the woman who was having an affair with her husband. Convicted of murder, La Coronela of Yautepec spent five years in Belén prison in Mexico. She was released in 1910 and returned to Morelos with her father, just at the time that Zapata was mounting his rebellion in Morelos against the landlords who had seized what remained of village and communal lands.

At loose ends, and hardened by some five years in prison, Maria de la Luz Espinosa Barrera volunteered for service with the Zapatistas on her return to Morelos. She, as did La Negra Angustias, donned male attire and wore male clothing for the duration of the Revolution. La Coronela, vividly recounting her first battle, remembered as if it were yesterday how she and her comrades could hear nothing but the chattering of their teeth and the nervous jingling of their spurs. As they waited for the

\footnotetext{
${ }^{94}$ I am grateful to Mrs. Anita Aguilar and Dr. Rosalind Rosoff Beimler of the American School in Mexico City and authors of Asi firmaron el Plan de Ayala ("SEP-SE'TEN'TAS," No. 241; Mexico, 1976), for introducing me to La Coronela. I attended three tape recording sessions in 1973 and 1974 in which Mrs. Aguilar and Dr. Beimler interviewed La Coronela of Yautepec as part of an oral history project to record the testimony of surviving Zapatistas in Morelos. La Coronela died in 1977.

${ }^{95}$ Mary Scalise Regoli, "La mujer en la novela de la revolución," p. 77
} 
enemy to approach, they tried to swallow but found that the saliva would not flow. Others were embarrassed by their incontinence.

In the end María de la Luz Espinosa Barrera proved herself in battle over and over again, and Emiliano Zapata himself signed the papers promoting her to lieutenant colonel. After his assassination she, like many of his loyal followers, left off fighting and returned to the ruins of their homes in Morelos. A restless soul, La Coronela became an itinerant vendor of clothing and found it impossible to conform to the accepted female role of passivity and timidity. Like the notorious Ensign Nun of the 17th century, La Coronela smoked, drank, gambled, and feared no man. Her eccentricity was, until her death in 1977, always accepted by her neighbors in Yautepec. ${ }^{96}$

La Coronela is but one of many admittedly unusual women who became officers and led men in battle during the Revolution. There was also Rosa Mójica Bobadilla of Jojutla and Amelia Robles, "El Guero" of Río Balsas who, in 1973, still wore male attire and still carried pistols. There were also other women soldiers and officers known by their nicknames, as "La Chata," "La Guera Carrasco," and "La Corredora." 97 Few of them received official recognition for their services during the Revolution and "La Coronela" was one of the few to live long enough to qualify for a modest pension as a veteran of that epic struggle. ${ }^{98}$

In sharp contrast to the tough and hardened soldaderas and women soldiers of the Revolution were the women who became the Revolution's victims. These were the timid and passive women, like Camila in Azuela's The Underdogs, who could not fend for themselves. During the worst years of the fighting, rape followed by murder became as commonplace as the routine shooting of prisoners. Hundreds of thousands of women (it is believed that as many as two million Mexicans perished between 1910 and 1920) died in the gratuitous slaughter that marked the period, or perished as a result of disease, exposure and hunger. ${ }^{99}$

There was a drastic decline in the food supply during the Revolution, ${ }^{100}$ and as Turner notes, "hunger, the specter that stalked all

\footnotetext{
${ }^{96}$ All the material on La Coronela is based on her own account as related in October 1973 in Yautepec, Morelos.

${ }^{97}$ I am grateful to Dr. Rosalind Rosoff Beimler for providing information on these women. See also Mendieta Alatorre, La mujer en la revolución mexicana, pp. 87 and 89-92.

${ }^{98}$ Ibid., p. 109.

${ }^{99}$ Cumberland, Mexico: The Struggle for Modernity, pp. 245-246.

${ }^{100} \mathrm{Ibid}$, pp. 247-248.
} 
Mexican cities and especially Mexico City, forced women into prostitution." 101 Even before the Revolution of 1910 Mexico City (the only city in the Republic for which we have figures) had a disproportionately large number of prostitutes. For instance, Dr. Luis Lara y Pardo found that in 1905 Mexico City had 11,554 registered prostitutes while an additional 4,371 unregistered prostitutes were apprehended that same year. ${ }^{102}$ This was out of a total population of 195,251 women, of whom 71,737 were in the age group of fifteen to thirty. Since $95 \%$ of the known prostitutes in Mexico City were in this age group, Lara y Pardo calculated that 120 women per thousand aged 15 to 30 were prostitutes, probably one of the highest figures of any city in the Americas or Europe at that time. ${ }^{103}$ These figures make clear the dreadful social imbalances in Mexico that led to the Revolution.

With food supplies declining, from 1910 to 1917 , to the levels of the late 18 th century, ${ }^{104}$ it is very possible that during the Revolution more than half the female population turned to prostitution in order to stay alive. The problem was so rampant that José Clemente Orozco did a particularly gruesome series of watercolors on prostitutes in Mexico City called "The House of Tears." 105 Degas and Toulouse Lautrec had treated prostitutes with some sympathy and understanding in their work, but in Orozco's series "the misogynist joins company with the uncompromising moralist who hates the sinner far more than the sin." 106 Orozco's attitude mirrored that of society in general, and prostitutes were treated as criminals rather than as victims by all but a handful of enlightened men and women. ${ }^{107}$ Only a few revolutionaries, as Salvador Alvarado, the pro-feminist Governor of Yucatan from 1915 to 1918, sought to help these despised women. The problem of exceedingly large

\footnotetext{
${ }^{101 '}$ Turner, The Dynamic of Mexican Nationalism, p. 191.

${ }^{102}$ Luis Lara y Pardo, La prostitución en México (México, 1908), pp. 19-20 and 26-27.

${ }^{103}$ In 1906 there were 4,000 known prostitutes in Paris, in a population five times larger than that of Mexico City. Ibid., pp. 19, 22 and 29.

${ }^{104}$ Cumberland, Mexico: The Struggle for Modernity, p. 247, notes that "corn, that great and necessary staple of the populace, had fallen to a point well below the 2-million-mark-a total production not significantly greater than that in the late eighteenth century and far less than the earlier period on a per capita basis."

${ }^{105}$ See James B. Lynch, "Orozco's House of Tears," Journal of Inter-American Studies, III (July, 1961), pp. 376-377,

${ }^{106}$ Ibid., p. 376.

${ }^{107}$ Dr. Luis Lara y Pardo demonstrated hostility and hatred toward the prostitutes he studied in his La prostitución en México. He did not believe them when they testified that they became prostitutes because of poverty or seduction and abandonment and insisted that most streetwalkers willingly gave up their virginity and then entered a life of vice with no effort whatsoever. See pp. $104 \mathrm{ff}$.
} 
numbers of prostitutes persisted in Mexico into the 1920s and 1930s, and the need to recognize and deal with this social malaise was emphasized by leading feminists in the post-revolutionary era.

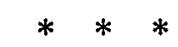

It is not difficult to see why many Mexicans, alienated by the brutality and thirst for revenge that was unleashed between 1910-1920, became enemies of the Revolution. This was especially true of middle and upper-class Catholics, men and women alike, who were horrified at the way churches were desecrated, statuary burned or used for target practice, and bishops, priests, and nuns abused and packed off to exile aboard freight cars. ${ }^{108}$

What happened during the Revolution was a culmination of an old conflict between Church and State. It began shortly after independence and tore the country apart from the 1830 s until 1876 , when Don Porfirio Díaz agreed to ignore the restrictions on the Church written into the 1857 constitution. That document had prohibited monastic vows and monastic establishments in Mexico. ${ }^{109}$ It also prohibited the Church from owning property other than Church buildings, ${ }^{110}$ and had given the Federal authorities exclusive power to "exercise, in matters of religious worship and outward ecclesiastical forms, such intervention as [is] by law authorized." 111 Lastly, the Constitution of 1857 defined marriage as a civil contract, which meant that persons married in a church service alone were not considered legally married by the civil authorities. ${ }^{112}$

The Constitution of 1857 was the work of an anti-clerical intelligentsia bent on modernizing Mexico. A distinct minority, these intellectuals did not reflect the beliefs and practices of the majority of mostly rural Mexicans, men, women and children. For the ordinary people religion

\footnotetext{
${ }^{108}$ See Quirk, op. cit., Pp. 54-60 for details of the ill-treatment of clergymen and nuns by such revolutionaries as Villa, Fierro, Obregón, Villarreal and others. A contemporary account of the mistreatment of nuns by Carrancistas is provided by P. R. Planchet, a priest in Devine, 'Texas, in $L a$ persecución a las religiosas y señoras, era Carrancista (n.p., 1922).

${ }^{109}$ Article 5 of the 1857 Constitution in Branch, ed., "The Mexican Constitution of 1917 compared with the Constitution of $1857, "$ p. 3.

${ }^{110}$ Article 27 in ibid., pp. 15-16.

${ }^{11}$ Article 123 in ibid., p. 103 . In seeming contradiction to this provision, the following section of Article 123 stated that "the church and state are independent of each other." The contradiction was noted by the constituent assembly in 1916-1917 and the phrase was dropped. See ibid., p. 103.

${ }^{112}$ Ibid., p. 104.
} 
was a pervasive force and an integral part of their lives. While religious influence undoubtedly declined between 1857 and 1910 among the $10 \%$ of the male and female population educated in laical schools, the rest of the nation continued in the old ways. The masses flocked to the shrines of the Indian Virgin of Guadalupe and to the Black Christ of Chalma. ${ }^{113}$ They continued to venerate the saints, celebrating their feast days with colorful fiestas, processions and ceremonies. Whether there were priests available to say mass or hear confession did not matter much; folk Catholicism could survive without the presence of clergy. ${ }^{114}$

This was not true for the elite Conservatives, who were formal and orthodox Catholics. Despite their political defeat by 1867 , they retained or regained their economic power and social prestige during the Porfiriato. Under their leadership and aided by the strong religious sentiments of the masses, the Catholic Church experienced a revival in the period from 1876 to 1910 . Monastic establishments reopened discreetly, and foreign clergy flocked to Mexico to minister to the needs of the more affluent Mexicans, whose children were sent to religious schools. The prohibitions against church ownership of property were circumvented and the contributions of the faithful made it possible for the hierarchy to live in relative splendor, and for the Church to run hospitals, orphanages, asylums and other charitable institutions. ${ }^{115}$

The circumvention of the religious provisions of the 1857 Constitution, the revival of Church influence and prestige, and the identification of the clergy with the rich and powerful and with the Porfirian regime angered the Mexican liberals and radicals who together brought down the dictatorship. The result was a new surge of anti-clerical and indeed anti-religious sentiment from 1910 to at least 1935 that once again tore the country apart. Martín Luis Guzmán stated in The Eagle and the Serpent that he knew only one revolutionary general who was a believer. ${ }^{116}$ The rest were either enemies of priests, like Villa, or enemies of religion altogether, like Obregón, Calles, Pablo González, Alvarado, Diéguez, Mújica, Jara, and countless other revolutionary generals. ${ }^{117}$

\footnotetext{
${ }^{113}$ The masses still flock to the Guadalupe and Chalma shrines. Of the former, the architect of the new basilica of Guadalupe in Mexico, Pedro Ramírez Vazquez, observed that the Guadalupe shrine "receives 1,500 pilgrimages and six million visitors per year. Even during Holy Year in 1975, St. Peter's in the Vatican only had six million visitors." Quoted in The New York Times, October 12, 1976, p. 10.

${ }^{114}$ For an illuminating review of religion and church-state relations in Mexico, see Frank 'Tannenbaum, Peace by Revolution. An Interpretation of Mexico (New York, 1933), pp. 34-67.

${ }^{115}$ Quirk, op. cit., p. 17.

${ }^{116}$ The general was Ramón F. Iturbe. Martín Luis Guzmán, Tbe Eagle and the Serpent (New York, $1965)$, p. 84.

${ }^{117}$ Quirk, op. cit, , pp. 54-60 and passim.
} 
The influence of these generals was paramount in the writing of the articles of the 1917 Constitution dealing with religious matters. The new constitution reiterated all the provisions of the 1857 document mentioned earlier, and in addition prohibited any religious corporation from imparting primary instruction. ${ }^{118}$ Churches were declared to be national property and the State legislatures were given the exclusive power "of determining the maximum number of ministers of religious creeds, according to the needs of each locality." 119 The 1857 Liberals had sought to curb the power of the Church and to reduce its influence among the people. The 1917 radicals were determined to succeed where their forbears had failed, even if it meant the complete destruction of religious freedom in Mexico.

Radical women like Juana Belén Gutiérrez, Dolores Jiménez y Muro, and Hermila Galindo shared the anti-clerical and anti-religious sentiments of their revolutionary colleagues. In addition, a large number of public school teachers and socially aware women workers were either neutral, indifferent or hostile to the Catholic Church, and it was from the ranks of these women that the feminist movement of the 1920s and 1930s was to draw its strength. But women from conservative families who were staunch defenders of the Catholic faith and its clergy, while not necessarily enjoying numerical superiority over secular-oriented women, were much more conspicuous than the latter in defense of their ideas. The revolutionaries were united only by their hatred of Díaz and Huerta, but were otherwise at odds, sometimes over ideas but oftentimes they were divided by purely personalistic considerations. In this situation, it was difficult for women who abhorred what Díaz and Huerta represented to be as noticeable as the women who were united in defense of something as concrete and palpable as the institutional church and specific members of its clergy.

The important state of Jalisco in western Mexico provides a good example of the active role conservative women played in defense of the Church between 1910 and 1920. Jalisco, it must be noted, was one of the most religious states in the Republic, and when free elections were held there in 1912, the voters, who were all male, of course, gave 43,000 votes to congressional candidates of the recently formed Catholic Party and only 12,900 votes to all other candidates. ${ }^{120}$ Given these figures, it is not

\footnotetext{
${ }^{118}$ Branch, ed., "The Mexican Constitution of 1917 Compared with the Constitution of 1857," p.

2.

${ }^{119}$ Article 130 in ibid., p. 104.

${ }^{120}$ Quirk, op. cit., p. 32.
} 
surprising that the Association of Catholic Women of the Archdiocese of Guadalajara (capital of Jalisco), established on April 26, 1913 at a meeting presided over by Archbishop Francisco Orozco y Jiménez, had 10,200 socias (members) within a year. ${ }^{121}$ By mid 1914 there were at least sixteen Catholic women's organizations in Guadalajara made up of teachers, white collar workers, maids, students, and housewives. ${ }^{22}$ As was true of all Catholic lay organizations in Mexico, these groups were controlled and directed by the hierarchy. ${ }^{123}$ When Archbishop Orozco y Jiménez was forced into exile from May 1914 to November 1916 another clergyman, Canon Luis Navarro, took over as director of the women's religious groups. ${ }^{124}$

Between 1913 and 1918, when the conflict between the civil authorities and the Church came to a head, the Association of Catholic Women of Guadalajara established a number of "Circulos de Estudios Femeninos" to prepare middle- and upper-class young women for social action. 'This social action consisted of establishing catechism classes for children being prepared for first communion, and of setting up day and night schools for working class children and working adults, respectively, to provide them with a religious education. ${ }^{125}$ Helped by a friendly press in Jalisco's capital, the socias distributed 100,000 copies of pro-clerical newspapers among their sympathizers. At Christmas in 1913, the socias also distributed 9,000 pieces of used clothing among the poor of Guadalajara. In May of 1914, just before Archbishop Orozco y Jiménez left Guadalajara, they set up a soup kitchen for the destitute adjoining Calvary Church in that city. ${ }^{126}$

The time of troubles for Catholics in Jalisco came when the Constitutionalist army, led by Carranza's chief military strategist, Alvaro Obregón, occupied Guadalajara in mid 1914. Obregón, soon to march on Mexico City, left a garrison there under the command of the rabidly anti-clerical General Manuel Diéguez. As happened in city after 'city occupied by the revolutionaries after the collapse of Victoriano Huerta's government, in late 1914 and early 1915 all the priests in Guadalajara

${ }^{121} \mathrm{~J}$. Ignacio Dávila Garibi, Memoria bistórica de las labores de la Asociación de Damas Católicas de Guadalajara (Guadalajara, Jal., 1920), pp. 3 and 5.

${ }^{122}$ Ibid., pp. 23-24.

${ }^{123}$ Speaking of the Confederation of Catholic Associations of Mexico, Quirk observes that "laymen were permitted to hold titular positions, but the key offices remained in the hands of the clergy, with most important posts being filled by episcopal appointments," Quirk, op. cit., p. 126.

${ }^{124}$ Dávila Garibi, Memoria bistórica, pp. 3 and 9.

${ }^{125}$ Ibid., pp. 5-6.

${ }^{126}$ Ibid., p. 6. 
were arrested and detained and then shipped out of the country. Nuns also were forced into exile. ${ }^{127}$ Diéguez closed every church in Guadalajara and the city remained "for many months without priests or Catholic schools." 128

While the women of Jalisco were in a state of shock for months, on Sunday, February 21, 1915, Catholic women in Mexico City organized a demonstration protesting the arrest of all the clergy in the capital. They clashed with a counter-demonstration led by radical workers of the Casa del Obrero Mundial, which resulted in two deaths and in many injuries. ${ }^{129}$ Tragic confrontations like this were to occur over and over again for the next fifteen years.

Between mid 1915 and early 1917, with Carranza now in full command of the Constitutionalist armies, the religious persecution lessened and Diéguez permitted some churches to reopen in Guadalajara and some clergy to return to their parishes. The conflict erupted again, however, in 1917 and 1918 and Catholic women played a prominent role in the events of those two years. At the end of July 1917, for example, several committees of Catholic women, lawyers and students went to Mexico City to protest in person to Carranza for the closing of churches of Guadalajara where the pastoral letter of Archbishop Orozco y Jiménez against the new constitution had been read. ${ }^{130}$ Then, in July 1918, Governor Diéguez issued Decrees 1913 and 1927, which were intended to enforce Article 130 of the new constitution by requiring that priests register with the public authorities. In addition, only one priest would be permitted to officiate for each 5,000 inhabitants. ${ }^{131}$

At the same time that Decrees 1913 and 1927 were being issued and approved by the State legislature, Archbishop Orozco y Jiménez was arrested and exiled again, packed off in a cattle car to the border. The protests against Orozco y Jiménez's second exile and Decrees 1913 and 1927 merged, ${ }^{132}$ and while the clergy ended all church services in Jalisco on September 1, 1918, the women of Jalisco directed an economic boycott in the State. The economic boycott proved so successful that on February 8, 1919 Governor Diéguez rescinded Decrees 1913 and 1927. When the Legislature approved his actions in March, the six month old

\footnotetext{
${ }^{127}$ Quirk, op. cit., p. 59.

${ }^{128}$ Ibid., p. 59.

${ }^{129}$ Ibid., p. 75 .

${ }^{130}$ Ibid., p. 106.

${ }^{131}$ Ibid., p. 107.

${ }^{132}$ Ibid., p. 109.
} 
economic paralysis came to an end and church services resumed. The crucial role women played in this first test of Article 130 was to be repeated in 1926, when the same tactics employed in Jalisco were attempted on a national scale. ${ }^{133}$ No wonder that all but a few male revolutionaries looked upon Mexican women as a threat to their cause. The positive contributions of women to the Revolution were ignored while the activities of Catholic women against its leaders were constantly kept in mind.

Women, then, played a very important and varied role in the Mexican Revolution, on the front, behind the lines, in favor of or against one of the most significant social revolutions of the twentieth century. Yet, except for occasional references to soldaderas, most historians of that epic struggle have ignored the active role of Mexican women in the Revolution as precursors, journalists, propagandists, political activists, and soldiers. Only artists and novelists have given serious attention to the way the Revolution victimized millions of women and, outside of religious publications, there has been a vast silence concerning the active role of women in opposing the Mexican Revolution in its anti-clerical aspects. In addition, to date very few historians have noticed that the Revolution acted as a catalyst for the acceleration of the women's movement in Mexico during and immediately after that struggle. ${ }^{134}$ By ignoring the active participation of millions of women in the Mexican Revolution, historians have helped to perpetuate the myth of Mexican women as weak, inert, passive and dependent human beings. The contrary is true, and in the course of the Mexican Revolution women, individually and in groups, demonstrated great courage, deep conviction, enormous resourcefulness, and a willingness to be actively involved in a cause in which they fervently believed.

Obio Wesleyan University

Anna Macias

Delaware, Obio

\footnotetext{
${ }^{133} I \mathrm{bid}$., pp. 110-111. The crucial role women played in the Jalisco boycott is fully explored in the anonymous booklet, La cuestion religiosa en Jalisco (México, 1918), pp. 48-74.

${ }^{134}$ On this point see Turner, Thy Dynamic of Mexican Nationalism, Mendieta Alatorre, La mujer en la revolución mexicana, p. 15, and Anna Macias, "The Mexican Revolution Was No Revolution. For Women," in Lewis Hanke, ed., History of Latin American Civilization: Sources and Interpretations. 2 vols. (2nd ed., Boston, 1973), II, 459-469.
} 